\title{
New records of Late Triassic wood from Argentina and their biostratigraphic, paleoclimatic, and paleoecological implications
}

\author{
Laura Vallejos Leiz, Alexandra Crisafulli, and Silvia Gnaedinger \\ Acta Palaeontologica Polonica 67 (2), 2022: 329-340 doi:https://doi.org/10.4202/app.00939.2021
}

We report gymnospermous wood found in sandstone and siltstone beds of the Upper Triassic Hilario Formation, Sorocayense Group at Hilario Creek located in San Juan province, Argentina. The identified xylotaphoflora comprises Baieroxylon cicatricum (Ginkgoales) and a new species of Protophyllocladoxylon (Coniferales), it constitutes the first reports of these taxa from the Triassic in Argentina. Protophyllocladoxylon hilarioense sp. nov. differs from the other species by the following combination of anatomical characters: radial pits araucarian, mixed and some with abietinian tendency, uni-biseriate; contiguous, separated; tangential pits uni-biseriate; cross-field pits are simple elliptic, oblique, one to two in number and low uni-biseriate rays. The growth rings in the reported woods show a gradual transition from earlywood to latewood, suggesting little change in the climatic conditions experienced during their growth. The type of growth rings observed is consistent with a humid but seasonally dry subtropical climate. These woods are representatives of the arboreal stratum of a mesophytic association.

Key words: Ginkgoales, Coniferales, Pinales,Baieroxylon, Protophyllocladoxylon, Triassic, Hilario Formation, Argentina, San Juan.

Laura Vallejos Leiz [lauravallejosleiz@gmail.com], Alexandra Crisafulli [alexandracrisafulli@hotmail.com], and Silvia Gnaedinger [scgnaed@hotmail.com], Centro de Ecología Aplicada del Litoral (CECOAL-CONICET-UNNE), Ruta 5 km 2,5, (3400), Corrientes, Argentina.

This is an open-access article distributed under the terms of the Creative Commons Attribution License (for details please see creativecommons.org), which permits unrestricted use, distribution, and reproduction in any medium, provided the original author and source are credited. 
Forif Full text $(2.975 .3 \mathrm{kB})$

PDFF' Supplementary file $(63.4 \mathrm{kB})$ 